\title{
The prevalence and determinants of pregnancy-related anxiety amongst pregnant women at less than 24 weeks of pregnancy in Bangalore, Southern India
}

This article was published in the following Dove Press journal:

International Journal of Women's Health

\author{
Anita Nath' \\ Shubhashree Venkatesh' \\ Sheeba Balan' \\ Chandra S Metgud ${ }^{2}$ \\ Murali Krishna ${ }^{3}$ \\ Gudlavalleti Venkata \\ Satyanarayana \\ Murthy ${ }^{4,5}$
}

'Indian Institute of Public Health Hyderabad-Bangalore Campus, Public Health Foundation of India, Bangalore, Karnataka, India; ${ }^{2}$ Department of Community Medicine, J.N. Medical College, KLE University, Belgavi, Karnataka, India; ${ }^{3}$ FRAMe, Mysore, Karnataka, India; ${ }^{4}$ Indian Institute of Public Health Hyderabad, Public Health Foundation of India, Hyderabad, Telangana, India; ${ }^{5}$ Department of Clinical Research, International Center for Evidence in Disability, London School of Hygiene and Tropical Medicine, London, UK
Correspondence: Anita Nath Indian Institute of Public Health Hyderabad-Bangalore Campus, Public Health Foundation of India, SIHFW Premises, First Cross Magadi Road, Bangalore 560023, Karnataka, India Tel +9l 9972384877

Email anitanath@iiphh.org
Background: A pregnant woman undergoes physiological as well as psychological changes during this phase of life during which anxiety is a commonly faced mental condition. There is sufficient evidence on the association of pregnancy specific anxiety with adverse pregnancy outcomes. Studies on anxiety during pregnancy from low and middle income countries are limited.

Methods: This study included 380 pregnant women, having a confirmed pregnancy of less than 24 weeks without any obstetric complication, who were availing of antenatal care at a public sector hospital in Bangalore city. Pregnancy-related thoughts (PRT) scale was used to screen for anxiety. Details pertaining to sociodemographic data, obstetric history, psychosocial factors including social support, marital discord, domestic violence, consanguinity, history of catastrophic events, history of mental illness, current presence of depression and anxiety was obtained by means of electronic data capture using an Android-based App.

Results: Out of 380 pregnant women, 195 (55.7\%) were found to have pregnancy-related anxiety. Lower socioeconomic status, low social support and depression emerged as significant determinants of anxiety.

Conclusion: The prevalence of anxiety was fairly high in the study population and isp therefore an important public health concern. Pregnancy-related anxiety must be identified early during routine antenatal care to prevent any untoward pregnancy outcomes.

Keywords: anxiety, pregnancy, prevalence, determinants, India

\section{Introduction}

Pregnancy is a time of joy and hopeful expectation although it could also be fraught with worries and anxiety about the physiological and emotional changes that take place during this time. While depression and anxiety are commonly occurring mental conditions during pregnancy, there is emerging evidence that presence of anxiety may be much more common than that of depression. ${ }^{1}$ Pregnancy anxiety is defined as a negative emotional state that is associated with worries about "the health and well-being of one's baby, the impending childbirth, of hospital and health-care experience (including one's own health and survival in pregnancy) during birth and parenting or maternal role." 2 It is considered to be distinct from the general indices of anxiety and depression in the non-pregnant state. ${ }^{3}$ In low- and middle-income countries, more importance 
is given towards addressing obstetric complications and reducing the maternal mortality; while a woman's emotional and mental health receives less attention than is due. ${ }^{4}$ Symptoms suggestive of a disturbed mental health such as poor sleep and tiredness are likely to be ignored and attributed to a normal physiological condition associated with pregnancy.

There is ample evidence that anxiety and similar mental conditions during pregnancy could increase the risk of adverse pregnancy outcomes and offspring neurodevelopment. ${ }^{5,6}$ The adverse outcomes include low birth weight, prolonged labour, preterm delivery and a higher incidence of caesarean section. ${ }^{7-10}$ When compared with general anxiety, pregnancy-related anxiety appears to be a stronger determinant for poor obstetric consequences. ${ }^{4}$

According to a systematic review, the prevalence of anxiety during pregnancy ranges from $1 \%$ to $26 \%$ in low- and middle-income countries (LMICs). ${ }^{11}$ However, published literature on anxiety during pregnancy seems to be limited. In a systematic review of common mental health morbidities during the antenatal period, it was found that evidence from LMICs' contributed to only $8 \%$ of included literature. ${ }^{12}$ The aim of this study was to determine the prevalence of anxiety and its determinants among pregnant women availing of antenatal care at a public sector hospital in Bangalore.

\section{Material and methods}

\section{Study area, participants and recruitment}

The study participants included pregnant women who were seeking care at Jaya Nagar General Hospital, which is a subdistrict hospital in Bangalore. This study was nested within an ongoing cohort study, the study protocol of which has been published earlier. ${ }^{13}$ The study participants were included according to the eligibility criteria of the study protocol. Pregnant women above the age of 18 years with a confirmed pregnancy of less than or equal to 6 months ( $\leq 24$ weeks) were included. Those diagnosed with obstetric complications and a recent intake of steroidal medication were excluded. The study analyzed the data of 350 eligible pregnant women who had completed baseline visit of the study during the period from August 2017 until July 2018.

\section{Ethical issues}

After an explanation about the nature and purpose of the study, the eligible pregnant women who agreed to participate were asked to give a signed consent. Privacy was ensured during data collection and all identifiers were removed to ensure data confidentiality. The Institutional Ethics Committee of the Indian Institute of Public Health, Bangalore campus (IIPHHB/TRCIEC/118/2017) gave approval for the study.

\section{Data elements}

A custom designed Android-based App Cascade version 2.0.0 developed by Athenaeum Technologies Private Limited was used for electronic data capture. Data included sociodemographic variables, obstetric history, psychosocial factors such as social support, marital discord, domestic violence, consanguinity, history of catastrophic events, history of mental illness, recent anxiety and depression.

\section{Measurement of dependent variables}

The Pregnancy-related thoughts (PRT) scale which was originally developed by Rini et al ${ }^{14}$ in 1999 was used to screen for the presence of anxiety. The scale is composed of ten questions, the initial five questions have been derived from a prenatal stress scale by Wadhwa et $\mathrm{al}^{15}$ in 1993, the remaining five items were added by Rini et al. Each item is scored on a 4-point scale with cut-off scores of 28 and 24 for nulliparous and multiparous women. The internal consistency (Cronbach's alpha) of PRT was seen to be 0.79 . The scale, originally in English language, was translated into the local language 'Kannada' and then back translated. The scale was pilot tested in a sample of 100 women and found to be reliable with a Cronbach's alpha of 0.80 .

\section{Measurement of possible determinants}

Modified Kuppuswamy socioeconomic scale was used to measure the socioeconomic status. ${ }^{16}$ The Revised Dyadic Adjustment Scale was used to explore marital relationship; it estimates seven domains of relationship between the partners within three categories: decision making, values and affection. ${ }^{17}$ Social support was gauged by using the Multidimensional Scale of Perceived Social Support Scale (MSPSS). ${ }^{18}$ The scale includes 12 questions and scoring is done on a 7-point Likert rating scale ranging from "very strongly disagree" to "very strongly agree." History of spouse physical and sexual violence was elicited by means of the Modified Conflict Tactics scale. ${ }^{19}$ The participants were screened for depression using the 10-item Edinburgh Postnatal Depression Scale (EPDS) ${ }^{20}$ The scale comprises of 10 short questions, those scoring above 12 or 13 are likely to be suffering from depression. 


\section{Statistical analysis}

Data were retrieved from the data server, cleaned and analyzed using SPSS version 22 (IBM Corporation, Armonk, NY, USA). The presence of anxiety using the PRT scale was indicated by a score of more than or equal to 28 for nulliparous women and more than or equal to 24 for multiparous women. The independent variables were categorized to analyze the association between each independent and outcome variable using a univariate analysis to calculate the Crude Odd's Ratio with 95\% Confidence Interval. Those variables that were found to be associated at a $P$ level $<0.2$ in the univariate analysis were entered into a multivariate logistic regression model to calculate the Adjusted Odd's Ratio and to eliminate the effects of confounding. A $P$-value of less than 0.05 for an association in the multivariable analysis was considered to be significant.

\section{Results}

\section{Sociodemographic characteristics of the study participants}

Almost two-thirds (70\%) of the study participants were above the age of 20 years and $72.3 \%$ belonged to the Muslim faith. Over one third of them had completed high school (38.6\%) while the spouses of $33.9 \%$ had completed pre-university college or diploma level education. The majority (92\%) were homemakers and the husbands of $51.8 \%$ were semiskilled workers. Over half $(57.4 \%)$ of them belonged to upper-lower socioeconomic status. The details are presented in Table 1.

The mean gestational age of the respondents was 17.6 \pm 4.1 weeks. As many as 309 respondents were between 13 and 24 weeks $(88.3 \%$ ) while the remaining $11.7 \%$ were less than 12 weeks of gestation.

\section{Prevalence of anxiety}

Out of 350 pregnant women, 195 (55.7\%) were found to have pregnancy-related anxiety The mean score obtained from the PRT scale according to the gestational age and parity is shown in Table 2. The group-wise mean score difference was not significant.

\section{Association of anxiety with sociodemographic characteristics}

As shown in Table 3, the Odd's of anxiety was more than twice as higher among women belonging to the lower middle class [AOR 2.804(1.296-6.068, $P=0.009)]$.
Table I Sociodemographic profile of study participants $(\mathrm{N}=350)$

\begin{tabular}{|c|c|c|}
\hline $\begin{array}{l}\text { Sociodemographic } \\
\text { characteristics }\end{array}$ & $\begin{array}{l}\text { Frequency } \\
(n=350)\end{array}$ & $\begin{array}{l}\text { Percentage } \\
(\%)\end{array}$ \\
\hline \multicolumn{3}{|l|}{ Age group } \\
\hline$\leq 20$ years & 105 & 30 \\
\hline$>20$ years & 245 & 70 \\
\hline \multicolumn{3}{|l|}{ Religion } \\
\hline Hinduism & 91 & 26.0 \\
\hline Christianity & 06 & 1.7 \\
\hline Islam & 253 & 72.3 \\
\hline \multicolumn{3}{|l|}{$\begin{array}{l}\text { Educational qualification of } \\
\text { the respondents }\end{array}$} \\
\hline Illiterate & II & 3.1 \\
\hline Primary school & 09 & 2.9 \\
\hline Middle school & 105 & 30.0 \\
\hline High school & 135 & 38.6 \\
\hline PUC or diploma & 65 & 18.6 \\
\hline Graduate & 25 & 7.1 \\
\hline \multicolumn{3}{|l|}{$\begin{array}{l}\text { Educational qualification of } \\
\text { the husbands }\end{array}$} \\
\hline Illiterate & 36 & 12.9 \\
\hline Primary school & 20 & 7.1 \\
\hline Middle school & 71 & 25.4 \\
\hline High school & 95 & 33.9 \\
\hline PUC or diploma & 36 & 12.9 \\
\hline Graduate & 22 & 7.8 \\
\hline Postgraduate & & \\
\hline \multicolumn{3}{|l|}{$\begin{array}{l}\text { Occupation of the } \\
\text { respondents }\end{array}$} \\
\hline Unskilled worker & 15 & 4.3 \\
\hline Semi-skilled worker & 12 & 3.4 \\
\hline Clerical or Farmer & 이 & 0.3 \\
\hline Housewife & 322 & 92.0 \\
\hline \multicolumn{3}{|l|}{ Occupation of the husbands } \\
\hline Unemployed & 01 & 0.4 \\
\hline Unskilled worker & 96 & 34.3 \\
\hline Semi-skilled worker & 145 & 51.8 \\
\hline Skilled worker & 35 & 12.5 \\
\hline Clerical or Farmer & 이 & 0.4 \\
\hline Semi professional & 02 & 0.7 \\
\hline \multicolumn{3}{|l|}{ Socioeconomic Status } \\
\hline Upper middle class & 43 & 12.3 \\
\hline Lower middle class & 106 & 30.3 \\
\hline Upper Lower class & 201 & 57.4 \\
\hline
\end{tabular}

\section{Association of anxiety with obstetric history}

There was no significant association between anxiety and obstetric variables as seen in Table 4 . 
Table 2 Mean PRA score according to gestational age and gravidity

\begin{tabular}{|l|l|l|}
\hline & Primigravida & Multigravida \\
\hline $\begin{array}{l}\text { Gestational age } \leq 12 \text { weeks } \\
\text { Gestational age }>12 \text { weeks to } \\
\leq 24 \text { weeks }\end{array}$ & $22.07 \pm 8.39$ & $19.6 \pm 12.4$ \\
\hline
\end{tabular}

\section{Association between anxiety and psychosocial factors}

The Odds of anxiety was significantly higher among women with low social support on univariate as well as multivariate analysis (COR 1.733 [0.945-3.178], AOR 1.683 [0.925-3.064]) (Table 5). The association of anxiety with marital discord was statistically significant $(P=0.051)$ although its strength was low (AOR 0.639 [0.402-1.008]). Similarly, association with spousal violence was weak (AOR, 0.258 [0.072-0.919]), although significant, $P=0.037$. Anxiety and depression appeared to be strongly and significantly associated (COR $=1.928[1.163-3.196]$, $P=0.011$, AOR, 1.965 [1.193-3.235], $P=0.008$ ).

\section{Discussion}

In this study, more than half of the pregnant women (55.7\%) were suffering from pregnancy-related anxiety during earlyto-mid pregnancyas determined by using the PRT scale. The reported prevalence rates using differing scales from other countries seem to be much lower- $23.6 \%$ in Saudi Arabia using the State Anxiety scale, ${ }^{21} 26.8 \%$ in Brazil using the Hospital Anxiety Subscale, ${ }^{22} 23 \%$ in South Africa using the Mini-International Neuropsychiatric Interview diagnostic interview and 25\% in Tanzania using the Pregnancy-related anxiety questionnaire. ${ }^{23,24}$

Among Indian studies, Madhavaprabhakaran et $\mathrm{al}^{25}$ with the help of the Pregnancy Specific Anxiety Scale (PSAS), found that all women during the first trimester had some degree of pregnancy specific anxiety, which was mostly the moderate form in $89.4 \%$ of the women. A lower prevalence rate of $28.4 \%$ throughout all the trimesters was seen among pregnant women in Bhubaneswar for which the Hospital Depression and Anxiety Scale was used for measurement. ${ }^{26}$ This disparity in the prevalence rates could be attributed to differences in the psychometric properties of measuring scales that were used; and also to the sociodemographic and sociocultural heterogeneity and diversity of the study population. Societal norms and values can also alter the perceptions of what may be considered to be "stressful" or "dangerous" hence accounting for this variation in the prevalence across different study settings. ${ }^{27}$

Among the sociodemographic factors, we could not demonstrate any relevant association of pregnancyrelated anxiety with age, respondent's education and occupation; and husband's education. Madhavaprabhakaran et $\mathrm{al}^{25}$ reported that younger women were at a higher risk for pregnancy-related anxiety. In regard to the relationship of anxiety with a woman's education, different studies report conflictive findings. While Lau and $\mathrm{Yin}^{28}$ (2011) contended that well educated women could handle stress in a better way during pregnancy; ${ }^{28}$ other authors claim that the stress levels could be much higher in this group. ${ }^{29,30}$

The burden of anxiety was seemingly higher among women who belonged to lower socioeconomic classes; which is in concurrence with other study results. ${ }^{31-34}$ However, Kingston et $\mathrm{al}^{35}$ (2012) and Renae Stancil et $\mathrm{al}^{36}$ (2000), found lower levels of stress in lower income group women.

We could not find any important linkage between anxiety and obstetric history, although many studies show higher levels of anxiety among primiparous women. ${ }^{37,38}$ Also, an unplanned pregnancy or a history of medical complaint did not appear to predispose to prenatal anxiety. This is contrary to the study findings on anxiety in pregnant women from the Netherlands wherein multiparity, a history of depression, episodes of severe nausea and extreme fatigue were strongly related with anxiety. ${ }^{39}$ Alqahtani et $\mathrm{al}^{21}$ in their research, also identified unplanned pregnancy and history of abortion to be significant predictors of anxiety. ${ }^{21}$ Likewise, van Heyningen et $\mathrm{al}^{23}$ confirmed that multigravidity, previous pregnancy loss and unplanned pregnancy could be significant predictors of antenatal anxiety.

Among the psychosocial factors, low social support emerged as a significant predictor of anxiety. The association of anxiety with marital discord was weak whereas none was seen with a recent history of catastrophic events. While spousal violence is a known stressor, ${ }^{40,41}$ paradoxically, in the present study the prevalence of anxiety was seemingly lower in respondents who were victims; this may be ascribed to a respondent bias in the form of nonreporting, most likely due to fear apprehension or an associated social stigma. Most cases of spousal violence go under-reported, the reported cases present the "tip of the iceberg. ${ }^{, 42}$ Increased perceived social and partner support appear to decrease the risk for antenatal anxiety as 
Table 3 Association between sociodemographic characteristics and anxiety among the pregnant women $(\mathrm{N}=350)$

\begin{tabular}{|c|c|c|c|c|c|c|}
\hline $\begin{array}{l}\text { Socio demographic } \\
\text { characteristics }\end{array}$ & $\begin{array}{l}\text { Non- } \\
\text { anxious } \\
(155)\end{array}$ & $\begin{array}{l}\text { Anxious } \\
(195)\end{array}$ & $\begin{array}{l}\text { Crude Odd's Ratio } \\
(95 \% \mathrm{Cl})\end{array}$ & $\begin{array}{l}P \text { - } \\
\text { value }\end{array}$ & $\begin{array}{l}\text { Adjusted Odd's } \\
\text { Ratio }(95 \% \mathrm{Cl})\end{array}$ & $\begin{array}{l}P \text { - } \\
\text { value }\end{array}$ \\
\hline $\begin{array}{l}\text { Age group } \\
\leq 20 \text { years }(10 \mathrm{I}) \\
>20 \text { years }(245)\end{array}$ & $\begin{array}{l}49(46.7 \%) \\
106(43.3 \%)\end{array}$ & $\begin{array}{l}56(53.3 \%) \\
139(56.7 \%)\end{array}$ & $\begin{array}{l}\text { I } \\
\text { I.246 (0.749-2.073) }\end{array}$ & 0.396 & & \\
\hline $\begin{array}{l}\text { Educational qualification of the } \\
\text { respondents } \\
<\text { High school }(225) \\
>\text { High school }(125)\end{array}$ & $\begin{array}{l}97(43.1 \%) \\
58(46.4 \%)\end{array}$ & $\begin{array}{l}128(56.9 \%) \\
67(53.6 \%)\end{array}$ & $\begin{array}{l}0.86 I(0.523-1.4 I 6) \\
I\end{array}$ & 0.555 & & \\
\hline $\begin{array}{l}\text { Educational Qualification of } \\
\text { the husbands } \\
<\text { High school (173) } \\
>\text { High school (177) }\end{array}$ & $\begin{array}{l}73(42.2 \%) \\
82(46.3 \%)\end{array}$ & $\begin{array}{l}100(57.8 \%) \\
95(53.7 \%)\end{array}$ & $\begin{array}{l}I .220(0.705-2.110) \\
I\end{array}$ & 0.477 & & \\
\hline $\begin{array}{l}\text { Occupation of the respondents } \\
\text { Working (28) } \\
\text { Housewife (322) }\end{array}$ & $\begin{array}{l}\text { II(39.3\%) } \\
\text { I } 44(44.7 \%)\end{array}$ & $\begin{array}{l}17(60.7 \%) \\
178(55.3 \%)\end{array}$ & $\begin{array}{l}0.960(0.388-2.377) \\
I\end{array}$ & 0.929 & & \\
\hline $\begin{array}{l}\text { Occupation of the husbands } \\
\text { Skilled workers (109) } \\
\text { Semi/unskilled workers (24I) }\end{array}$ & $\begin{array}{l}36(33 \%) \\
119(49.4 \%)\end{array}$ & $\begin{array}{l}73(67 \%) \\
122(50.6 \%)\end{array}$ & $\begin{array}{l}\text { I } \\
0.528(0.305-0.912)\end{array}$ & 0.665 & $0.545(0.320-0.930)$ & 0.988 \\
\hline $\begin{array}{l}\text { Socioeconomic Status } \\
\text { Upper middle class (43) } \\
\text { Lower middle class (I06) } \\
\text { Upper Lower class (20I) }\end{array}$ & $\begin{array}{l}27(62.8 \%) \\
43(40.6 \%) \\
85(42.3 \%)\end{array}$ & $\begin{array}{l}16(37.2 \%) \\
63(59.4 \%) \\
116(57.7 \%)\end{array}$ & $\begin{array}{l}I \\
0.586(0.34 I-I .009) \\
I .733(0.945-3.178)\end{array}$ & $\begin{array}{l}0.054 \\
0.075\end{array}$ & $\begin{array}{l}2.804(1.296-6.068) \\
1.963(0.934-4.116)\end{array}$ & $\begin{array}{l}0.009 \\
0.075\end{array}$ \\
\hline
\end{tabular}

Table 4 Association of obstetric history with anxiety among the pregnant women $(\mathrm{N}=350)$

\begin{tabular}{|c|c|c|c|c|}
\hline Obstetric and Medical History & $\begin{array}{l}\text { Non- anxious mothers } \\
(n=\mid 55)\end{array}$ & $\begin{array}{l}\text { Anxious mothers } \\
(n=\mid 95)\end{array}$ & Crude OR $(95 \% \mathrm{Cl})$ & $P$ value \\
\hline \multicolumn{5}{|l|}{ Gravida } \\
\hline Primigravida (143) & $65(45.5 \%)$ & 78 (54.5\%) & 1 & 0.918 \\
\hline Multigravida (207) & $90(43.5 \%)$ & $117(56.5 \%)$ & $0.918(0.358-2.353)$ & \\
\hline \multicolumn{5}{|l|}{ Parity } \\
\hline Primipara (I55) & $72(46.5 \%)$ & $83(53.5 \%)$ & 1 & \\
\hline Multipara (195) & $83(42.6 \%)$ & II $2(57.4 \%)$ & $1.718(0.50 \mathrm{I}-2.743)$ & 0.715 \\
\hline \multicolumn{5}{|l|}{ Abortion } \\
\hline Yes (82) & $38(46.3 \%)$ & $44(53.7 \%)$ & $0.904(0.475-1.72 I)$ & 0.758 \\
\hline No $(268)$ & 117 (43.7\%) & I5I (56.3\%) & I & \\
\hline \multicolumn{5}{|l|}{ Pregnancy Unplanned } \\
\hline Yes $(148)$ & $64(43.2 \%)$ & $84(56.8 \%)$ & $1.068(0.607-\mathrm{I} .702)$ & 0.783 \\
\hline No (202) & 91 (45\%) & III (55\%) & 1 & \\
\hline \multicolumn{5}{|l|}{ History of medical complications } \\
\hline Yes (26) & $12(46.2 \%)$ & $14(53.8 \%)$ & $0.865(0.328-0.284)$ & 0.771 \\
\hline No (324) & $143(44.1 \%)$ & $181(55.9 \%)$ & 1 & \\
\hline
\end{tabular}


Table 5 Association between psychosocial factors and anxiety among the pregnant mothers $(\mathrm{N}=350)$

\begin{tabular}{|c|c|c|c|c|c|c|}
\hline $\begin{array}{l}\text { Social Support \& Spouse physical } \\
\text { and Sexual violence }\end{array}$ & $\begin{array}{l}\text { Non- } \\
\text { Anxious } \\
\text { (I55) }\end{array}$ & $\begin{array}{l}\text { Anxious } \\
(195)\end{array}$ & $\begin{array}{l}\text { Crude OR } \\
(95 \% \mathrm{CI})\end{array}$ & $\begin{array}{l}P \\
\text { value }\end{array}$ & $\begin{array}{l}\text { Adjusted OR } \\
(95 \% \mathrm{Cl})\end{array}$ & $\begin{array}{l}\text { P- } \\
\text { value }\end{array}$ \\
\hline \multicolumn{7}{|l|}{ Social Support } \\
\hline High Support (I to 2.9) (I72) & $73(42.4 \%)$ & $99(57.6 \%)$ & $0.586(0.94 \mid-1.009)$ & I & $0.567(0.335-0.960)$ & \\
\hline Moderate Support (3 to 5) (98) & $58(59.2 \%)$ & $40(40.8 \%)$ & $1.733(0.945-3.178)$ & 0.054 & $1.683(0.925-3.064)$ & 0.035 \\
\hline Low Support (5.I to 7) (80) & $24(30 \%)$ & $56(70 \%)$ & & 0.075 & & 0.088 \\
\hline \multicolumn{7}{|l|}{ Marital Discord } \\
\hline No (159) & $63(39.6 \%)$ & $96(60.4 \%)$ & $0.613(0.382-0.983)$ & I & & \\
\hline Yes (19I) & $92(48.2 \%)$ & $99(51.8 \%)$ & & 0.042 & $0.639(0.402-1.008)$ & 0.051 \\
\hline \multicolumn{7}{|l|}{ Spouse Physical and Sexual Violence } \\
\hline Yes (I3) & $9(69.2 \%)$ & $4(30.8 \%)$ & $0.247(0.749-4.107)$ & 0.035 & $0.258(0.072-0.919)$ & 0.037 \\
\hline No (337) & 146 (43.3\%) & 191 (56.7\%) & & I & & \\
\hline \multicolumn{7}{|l|}{ Depression } \\
\hline Depressed (I23) & $43(35 \%)$ & $80(65 \%)$ & 1.928 & 0.011 & 1.965 & 0.008 \\
\hline Non-depressed (227) & $112(49.3 \%)$ & $115(50.7 \%)$ & $(1.163-3.196)$ & 1 & $(1.193-3.235)$ & \\
\hline \multicolumn{7}{|l|}{ Consanguinity } \\
\hline Not a relative $(240)$ & $103(42.9 \%)$ & $(57.1 \%) \quad 137$ & & I & & \\
\hline Relative (I I0) & $52(47.3 \%)$ & $58(52.7 \%)$ & $0.783(0.475-1.292)$ & 0.339 & & \\
\hline \multicolumn{7}{|l|}{ Past $\mathrm{H} / \mathrm{O}$ catastrophic events } \\
\hline Absent (265) & II 8 (44.5\%) & I 47 (55.5\%) & & I & & \\
\hline Present (85) & $37(43.5 \%)$ & $48(56.5 \%)$ & $1.060(0.616-1.822)$ & 0.834 & & \\
\hline
\end{tabular}

observed in other study settings. ${ }^{43}$ The prevalence of anxiety was significantly higher among women who were depressed in the present study. The co-morbid existence of depression and anxiety is frequently encountered, although the mechanism behind this and timing of which appears first is yet to be ascertained. ${ }^{24,36,44}$

\section{Study limitations}

This study was conducted in an urban public sector hospital setting where antenatal care is mostly availed by pregnant women belonging to the lower- and middleincome groups in a community. Hence, the findings from this study may not be applicable for pregnant women belonging to higher socioeconomic group as a result of variations in psychosocial factors and standard of living. The chance of selection bias is higher in a single hospitalbased cohort. The PRT scale, though not validated for use in the Indian population, was field tested for feasibility and reliability in a small sample of participants As a part of the cohort study protocol, women with high risk pregnancies and those with a history of recent intake of steroidal medication were excluded which could impede the generalizability of the study result. The counterintuitive finding of lower rates of spousal violence in the anxiety group could be attributed to respondent bias due to under-reporting of cases.

\section{Conclusion}

The prevalence of anxiety was fairly high in the study population and was strongly associated with lower socioeconomic status, low social support and depression. is important that pregnancy-related anxiety be identified and addressed during routine antenatal care to prevent associated adverse pregnancy outcomes. Future research should be focused upon widespread community- based studies to estimate prevalence of anxiety in a general population of pregnant women as much of the estimates in the current literature are derived from hospital-based studies. There is also a need to explore the neuroendocrinal factors and 
physiologic pathways that could possibly be associated with antenatal anxiety.

\section{Acknowledgments}

This work was supported by the Wellcome Trust DBT India Alliance grant fellowship [IA/CPHI/16/1/502634] awarded to Anita Nath.

\section{Disclosure}

The authors report no conflicts of interest in this work.

\section{References}

1. Heron J, O'Connor TG, Evans J, Golding J, Glover V. The course of anxiety and depression through pregnancy and the postpartum in a community sample. $J$ Affect. Disorder. 2004;80:65-73. doi:10.1016/j.jad.2003.08.004

2. Dunkel Schetter C. Psychological science on pregnancy: stress processes, biopsychosocial models, and emerging research issues. Аnnu Rev Psychol. 2011;62:531-558. doi:10.1146/annurev.psych.031809.130727

3. Huizink AC, Mulder EJH, Robles de Medina PG, Visser GHA, Buitelaar JK. Is pregnancy anxiety a distinctive syndrome? Early Hum Dev. 2004;79:81-91. doi:10.1016/j.earlhumdev.2004.04.014

4. Rahman A, Patel V, Maselko J, Kirkwood B. The neglected ' $m$ ' in $\mathrm{MCH}$ programmes-why mental health of mothers is important for child nutrition. Trop Med Int Health. 2008;13(4):579-583. doi:10.1111/j.1365.2008.02036.x

5. Bonari L, Pinto N, Ahn E, Einarson A, Steiner M, Koren G. Perinatal risks of untreated depression during pregnancy. Can J Psychiatry. 2004;49(11):726-735. doi:10.1177/070674370404901103

6. Alder J, Fink N, Bitzer J, Hösli I, Holzgreve W. Depression and anxiety during pregnancy: a risk factor for obstetric, fetal and neonatal outcome? A critical review of the literature. $J$ Matern Fetal Neonatal Med. 2007;20(3):189-209. doi:10.1080/ 14767050701209560

7. Shiva KBK, Krishnamurthy CN. Psychological factors affecting outcome of pregnancy. Ahhs. 2015;2(1):44-49. doi:10.5958/23220422.2015.00010.7

8. Niemi M, Falkenberg T, Petzold M, Chuc NT, Patel V. Symptoms of antenatal common mental disorders, preterm birth and low birthweight: a prospective cohort study in a semi-rural district of Vietnam. Trop Med Int Health. 2013;18(6):687-695. doi:10.1111/ tmi.12101

9. Yang S, Yang R, Liang S, et al. Symptoms of anxiety and depression during pregnancy and their association with low birth weight in Chinese women: a nested case control study. Arch Womens Ment Health. 2017;20(2):283-290. doi:10.1111/tmi.12101

10. Nasreen HE, Kabir ZN, Forsell Y, Edhborg M. Low birth weight in offspring of women with depressive and anxiety symptoms during pregnancy: results from a population-based study in Bangladesh. BMC Public Health. 2010;10:515. doi:10.1186/1471-2458-10-515

11. Jha S, Salve HR, Goswami K, Sagar R, Kant S. Burden of common mental disorders among pregnant women: A systematic review. Asian J Psychiatr. 2018;36:46-53. doi:10.1016/j.ajp.2018.06.020

12. Fisher J, Cabral de Mello M, Patel V, et al. Prevalence and determinants of common perinatal mental disorders in women in low- and lower-middle-income countries: a systematic review. Bull World Health Organ. 2012;90:139-149. doi:10.2471/BLT.11.091850

13. Nath A, Murthy G, Babu G, Di Renzo G. Effect of prenatal exposure to maternal cortisol and psychological distress on infant development in Bengaluru, southern India: a prospective cohort study. $B M C$ Psychiatry. 2017;17(1):255. doi:10.1186/s12888-017-1424-x
14. Rini CK, Dunkel-Schetter C, Wadhwa PD, Sandman CA. Psychological adaptation and birth outcomes: the role of personal resources, stress, and sociocultural context in pregnancy. Health Psychol. 1999;18(4):333-345. doi:10.1037/0278-6133.18.4.333

15. Wadhwa PD, Sandman CA, Porto M, Dunlosky J, Garite TJ. The association between prenatal stress and infant birth weight and gestational age at birth: a prospective investigation. Am J Obstet Gynecol. 1993;169:858-865. doi:10.1016/0002-9378(93)90016-C

16. Shaikh Z, Pathak R. Revised Kuppuswamy and B G Prasad socio-economic scales for 2016. Int J Community Med Public Health. 2017;4:997-999. doi:10.18203/2394-6040.ijcmph2017 1313

17. Crane DR, Middleton KC, Bean RA. Establishing criterion scores for the Kansas marital satisfaction scale and the revised dyadic adjustment scale. Am J Fam Ther. 2000;28(1):53-60. doi:10.1080/ 019261800261815

18. Zimet GD, Dahlem NW, Zimet SG, Farley GK. The Multidimensional Scale of Perceived Social Support. J Pers Assess. 1988;52:30-41. doi:10.1080/019261800261815

19. Straus M, Gelles R. Causes and Consequences of Violence against Women. Physical Violence in 8145 American Families: Risk Factors and Adaptations to Violence. Family Relations. New Brunswick, NJ: Transaction Publishing; 1990:49-73.

20. Cox JL, Holden JM, Sagovsky R. Detection of postnatal depression: development of the 10-item Edinburgh postnatal depression scale. $\mathrm{Br}$ J Psychiatry. 1987;150:782-786. doi:10.1192/bjp.150.6.782

21. Alqahtani AH, Al Khedair K, Al-Jeheiman R, Al-Turki HA, Al Qahtani NH. Anxiety and depression during pregnancy in women attending clinics in a university hospital in eastern province of Saudi Arabia: prevalence and associated factors. Int $J$ Womens Health. 2018;10:101-108. doi:10.2147/IJWH.S153273

22. Silva MMJ, Nogueira DA, Clapis MJ, Leite EPRC. Anxiety in pregnancy: prevalence and associated factors. Rev Esc Enferm USP. 2017;51:e03253. doi:10.1590/S1980-220X2016048003253

23. van Heyningen $\mathrm{T}$, Honikman S, Myer L, Onah MN, Field S, Tomlinson M. Prevalence and predictors of anxiety disorders amongst low-income pregnant women in urban South Africa: a cross-sectional study. Arch Womens Ment Health. 2017;20 (6):765-775. doi:10.1007/s00737-017-0768-z

24. Wall V, Premji SS, Letourneau N, McCaffrey G, Nyanza EC. Factors associated with pregnancy-related anxiety in Tanzanian women: a cross sectional study. BMJ Open. 2018;8(6):e020056. doi:10.1136/ bmjopen-2017-020056

25. Madhavanprabhakaran GK, D'Souza MS, Nairy KS. Prevalence of pregnancy anxiety and associated factors. IJANS. 2015;3:1-7.10.1016/j. ijans.2015.06.002.

26. Priyambada K, Pattojoshi A, Baklava AK. A study of antenatal anxiety: comparison across trimesters. Int $J$ Reprod Contracept Obstet Gynecol. 2017;6(5):1810-1813. doi:10.18203/2320-1770. ijrcog20171504

27. Lazarus RS, Folkman S. Stress, Appraisal, and Coping. New York, NY: Springer; 1984.

28. Lau Y, Yin L. Maternal, obstetric variables, perceived stress and health-related quality of life among pregnant women in Macao, China. Midwifery. 2011;27(5):668-673. doi:10.1016/j.midw.2010. 02.008

29. Goyal D, Gay C, Lee KA. How much does low socioeconomic status increase the risk of prenatal and postpartum depressive symptoms in first-time mothers? Women's Health Issues. 2010;20(2):96-104. doi:10.1016/j.whi.2009.11.003

30. Woods SM, Melville JL, Guo Y, Fan M-Y GA. Psychosocial stress during pregnancy. Am J Obstet Gynecol. 2010;202(1):e61-e67. doi:10.1016/j.ajog.2009.07.041

31. Shishehgar S, Dolatian M, Majd HA, Bakhtiary M. Socioeconomic status and stress rate during pregnancy in Iran. Glob J Health Sci. 2014;6 (4):254-260. 10.5539/gjhs.v 6n4p254. DOI:10.5539/gjhs.v6n4p254 
32. Farkas C, Valdés N. Maternal stress and perceptions of self-efficacy in socioeconomically disadvantaged mothers: an explicative model. Infant Behav Dev. 2010;33(4):654-662. doi:10.1016/j.infbeh.2010.09.001

33. Lever JP. Poverty, stressful life events, and coping strategies. Span J Psychol. 2008;11(1):228-249. doi:10.1017/S1138741600004273

34. Matthews KA, Gallo LC, Taylor SE. Are psychosocial factors mediators of socioeconomic status and health connections? Ann N Y Acad Sci. 2010;1186(1):146-173. 10.1111/j.1749-6632.2009.05332. x. DOI:10.1111/j.1749-6632.2009.05332.x

35. Kingston D, Heaman M, Fell D, Dzakpasu S, Chalmers B. Factors associated with perceived stress and stressful life events in pregnant women: findings from the Canadian maternity experiences survey. Matern Child Health J. 2012;16(1):158-168. doi:10.1007/s10995010-0732-2

36. Renae Stancil T, Hertz-Picciotto I, Schramm M, Watt-Morse M. Stress and pregnancy among African-American women. Paediatr Perinat Epidemiol. 2000;14(2):127-135. doi:10.1046/j.1365-3016.2000.00257.x

37. Öhmann SG, Grunewald C, Walndenström U. Women's worries during pregnancy: testing the Cambridge Worry Scale on 200 Swedish women. ScandJ Caring Sci. 2003;17:148-152 10. 1046/j.1471-6712.2003. 00095.x. doi:10.1046/j.1471-6712.2003. 00095.x.

38. Lobel M, Cannella DL, Graham JE, DeVincent C, Schneider J, Meyer BA. Pregnancy-specific stress, prenatal health behaviors, and birth outcomes. Health Psychol. 2008;27:604-615. doi:10.1037/ a0013242
39. van de Loo KFE, Vlenterie R, Nikkels SJ, et al. Depression and anxiety during pregnancy: the influence of maternal characteristics. Birth. 2018;45:478-489. doi:10.1111/birt.12343

40. Nasreen HE, Kabir ZN, Forsell Y, Edhborg M. Prevalence and associated factors of depressive and anxiety symptoms during pregnancy: a population-based study in rural Bangladesh. BMC Women's Health. 2011;11:22. doi:10.1186/1472-6874-11-22

41. Onoye JM, Shafer LA, Goebert DA, Morland LA, Matsu CR, Hamagami F. Changes in PTSD symptomatology and mental health during pregnancy and postpartum. Arch Womens Ment Health. 2013;16:453-463. doi:10.1007/s00737-013-0365-8

42. Gracia E. Unreported cases of domestic violence against women: towards an epidemiology of social silence, tolerance, and inhibition. J Epidemiol Community Health. 2004;58:536-537. doi:10.1136/ jech.2003.019604

43. Cheng ER, Rifas-Shiman SL, Perkins M, et al. The influence of antenatal partner support on pregnancy outcomes. $J$ Womens Health (Larchmt). 2016;25:672-679. doi:10.1089/jwh.2015.5462

44. Field T, Diego M, Hernandez-Reif M, et al. Comorbid depression and anxiety effects on pregnancy and neonatal outcome. Infant Behav Dev. 2010;33:23-29. doi:10.1016/j.infbeh.2009.10.004

\section{Publish your work in this journal}

The International Journal of Women's Health is an international, peerreviewed open-access journal publishing original research, reports, editorials, reviews and commentaries on all aspects of women's healthcare including gynecology, obstetrics, and breast cancer. The manuscript management system is completely online and includes a very quick and fair peer-review system, which is all easy to use. Visit http://www.dovepress.com/testimonials.php to read real quotes from published authors. 